\title{
DINAMIKA HARGA MINYAK GORENG SAWIT ( MGS ) DAN DAMPAKNYA TERHADAP PERKEBUNAN KELAPA SAWIT INDONESIA
}

\author{
Novalina Sinurat ${ }^{1)}$, Zulkifli Alamsyah ${ }^{2)}$ dan Elwamendri ${ }^{2)}$ \\ Email : sinuratnovalina@rocketmail.com
}

1) Alumni Program studi Agribisnis Fakultas Pertanian Universitas Jambi

2) Dosen Program Studi Agribisnis Fakultas Pertanian Universitas Jambi

\begin{abstract}
ABSTRAK
Penelitian ini bertujuan untuk mempelajari dinamika harga Minyak Goreng Sawit (MGS) dan menganalisis dampak dari dinamika harga minyak goreng sawit terhadap perkembangan perkebunan kelapa sawit di Indonesia yang dilihat dari perkembangan luas areal dan produktivitas perkebunan kelapa sawit di Indonesia. Metode analisis yang digunakan adalah metode pendekatan model ekonometrika persamaan simultan dengan metode $2 S L S$, melalui program aplikasi SAS versi 9.1.3. Penelitian ini menggunakan data sekunder dari instansiinstansi terkait selama 23 tahun yaitu periode 1990-2012. Dinamika harga minyak goreng sawit di Indonesia secara dominan dipengaruhi oleh permintaan, penawaran dan harga CPO. Dari sisi supply dipengaruhi signifikan dan sesuai teori ekonomi oleh produksi MGS, stok MGS, kebijakan Domestic Market Obligation (DMO). Dari sisi demand dipengaruhi signifikan oleh lag satu tahun demand MGS. Namun demikian perubahan dari faktor-faktor kebijakan pada sisi supply dan demand dapat berdampak terhadap kinerja pada subsektor perkebunan kelapa sawit melalui respon luas areal dan respon produktivitas kelapa sawit. Simulasi penurunan stok minyak goreng sawit sebesar $5 \%$ akan direspon positif oleh luas areal dan produktivitas kelapa sawit masing-masing sebesar $1,42 \%$ dan $0,15 \%$, demikian juga simulasi peningkatan pendapatan perkapita masyarakat sebesar $15 \%$ akan merespon peningkatan luas areal dan produktivitas kelapa sawit masing-masing sebesar $0,035 \%$ dan $0,05 \%$ dan simulasi peningkatan harga minyak goreng kelapa sebesar $10 \%$ akan merespon peningkatan luas areal dan produktivitas kelapa sawit masing-masing sebesar $0,16 \%$ dan $0,02 \%$.
\end{abstract}

Kata kunci : Harga, Minyak Goreng sawit, Kelapa Sawit

\begin{abstract}
This research aims to study the dynamics of Palm Cooking Oil (PCO) prices and analyze the impact of PCO price dynamics on the development of palm oil plantations in Indonesia, as seen from the development of acreage and productivity of palm oil plantations in Indonesia. The analytical method used is the method of econometric modeling approaches, called simultaneous equations with $2 S L S$ method, via the application program SAS version 9.1.3. This study uses secondary data from relevant agencies for 23 years the period is 1990-2012. The dynamics of the price of PCO in Indonesia is predominantly influenced by the demand and supply PCO and price of CPO. From the supply side affected significantly by the production of $P C O, P C O$ stock and DMO policy. From the demand side is influenced significantly by one-year lag demand of PCO. However, the change of policy factors on the supply side and demand, can affect the performance of the palm oil sub-sector through the acreage response and the palm oil productivity response. Simulation of PCO stocks decrease by 5\% will be response positively by acreage and productivity of palm oil respectively $1.42 \%$ and $0.15 \%$, as well as an increase in income per capita of community that simulated increase by 15\% will increase in
\end{abstract}


acreage and productivity palm oil respectively $0.035 \%$ and $0.05 \%$ and the simulation an increase in the price of coconut cooking oil by $10 \%$ will respond to an increase in acreage and productivity of palm oil respectively $0.16 \%$ and $0.02 \%$.

Keyword : Price, Palm Cooking Oil, Oil Palm

\section{PENDAHULUAN}

Minyak goreng merupakan salah satu bahan makanan pokok yang dikonsumsi oleh seluruh masyarakat Indonesia, baik yang tinggal dipedesaan maupun diperkotaan. Oleh karena itu, minyak goreng dapat pula dikategorikan sebagai komoditas yang cukup strategis karena pengalaman selama ini menunjukkan bahwa kelangkaan minyak goreng dapat menimbulkan dampak ekonomis dan politis yang cukup berarti bagi perekonomian Nasional (Amang et al, 1996). Sumber bahan baku utama minyak goreng yang di produksi Indonesia adalah kelapa sawit dalam bentuk minyak dan inti sawit, dan kelapa dalam bentuk kopra. Saat ini pangsa produksi minyak goreng sawit semakin meningkat dan sebagian besar adalah minyak goreng berbahan baku kelapa sawit. Kebutuhan minyak goreng yang meningkat seiring dengan peningkatan jumlah penduduk tiap tahunnya tentu saja perlu diiringi dengan peningkatan produktivitas kelapa sawit sebagai bahan bakunya.

Penyediaan minyak goreng sawit, tidak terlepas dari ketersediaan bahan bakunya yaitu Crude Palm Oil yang merupakan olahan dari TBS (Tandn Buah Segar). Harga CPO yang digunakan dalam pembuatan minyak goreng sawit mempunyai hubungan timbal balik dan keterkaitan yang erat dengan harga minyak goreng sawit sebagai salah satu produk hilirnya. Harga CPO domestik terintegrasi dengan harga ekspor CPO. Bila harga ekspor CPO tinggi maka CPO akan diekspor keluar negeri sehingga pasokan dalam negeri akan menurun atau bahkan tidak mencukupi konsumsi CPO dalam negeri yang akan mengakibatkan harga CPO sebagai bahan baku pembuatan minyak goreng meningkat. Permintaan dan penawaran juga merupakan fungsi dari harga dan jumlah barang yang diminta. Akan tetapi harga suatu barang tidak hanya dipengaruhi oleh permintaan dan penawaran saja, tetapi dipengaruhi juga oleh harga barang lain dan harga input produksi (Soekartawi, 2002). Bila dilihat dari sisi pengaruh harga CPO terhadap harga minyak goreng sawit, semakin tinggi harga CPO maka harga minyak goreng tentu akan semakin tinggi pula, karena biaya yang dikeluarkan untuk input produksi akan semakin besar. Apabila dilihat dari segi permintaan minyak goreng sawit, semakin tinggi permintaan terhadap minyak goreng sawit, maka permintaan CPO juga akan meningkat dan akan berdampak pula terhadap harga CPO. Harga CPO yang meningkat akan meningkatkan produksi CPO dimana permintaan kelapa sawit sebagai bahan bakunya akan meningkat yang akan menstimulasi peningkatan harga dipihak produsen. Peningkatan harga merupakan insentif bagi petani dalam meningkatkan produksi dengan cara meningkatkan luas areal dan produktivitas kelapa sawit.

Dalam salah satu penelitian terdahulu disimpulkan bahwa dampak kebijakan harga beras berpengaruh positif terhadap kesejahteraan petani melalui sisi penawaran yang ditunjukkan oleh kebijakan harga dasar gabah dan ratio harga pupuk terhadap harga beras terhadap respon areal tanam dan produktivitas padi (Rahayu, 2008). Oleh karena harga (dalam hal ini harga minyak goreng) diduga berdampak terhadap luas areal dan produksi kelapa sawit, maka faktor-faktor yang mempengaruhi harga minyak goreng tersebut juga harus perlu diketahui. Berdasarkan uraian diatas, penulis tertarik untuk meneliti dinamika harga minyak goreng sawit yang terjadi di Indonesia dan dampaknya terhadap perkebunan kelapa sawit di Inonesia.

\section{METODE PENELITIAN}

Penelitian ini menggunakan data sekunder dengan ruang lingkup Indonesia. Data yang digunakan adalah data time series selama 23 tahun terakhir periode 1990-2012. Pengambilan data diambil dari instansi terkait dan dari studi literatur terkait yaitu dengan mengutip dan menyalin data 
yang dimaksudkan untuk memperoleh sumber pengetahuan bersifat teoritis yang berhubungan dengan objek penelitian dan laporan-laporan hasil penelitian. Metode analisis data yang digunakan dalam penelitian ini adalah analisis deskriptif dan kuantitatif. Metode analisis kuantitatif yang digunakan merupakan metode pendekatan model ekonometrika persamaan simultan (simultaneous -equation) dengan metode Two Stages Least Square (2SLS), melalui program aplikasi Statistical Analisys System (SAS) versi 9.1.3.

Persamaan simultan adalah suatu persamaan yang menggambarkan ketergantungan diantara berbagai peubah dalam persamaan tersebut sehingga membentuk suatu sistem persamaan.

Berikut adalah model ekonometrik fungsi struktural dan fungsi identitas minyak goreng sawit dan hubungannya dengan perkembangan luas areal dan produktivitas kelapa sawit yang diformulasikan dalam bentuk persamaan sebagai berikut :

1. Fungsi struktural harga minyak goreng $\mathrm{HRMGS}_{\mathrm{t}}=\mathrm{a} 0+\mathrm{a} 1 \mathrm{SPMGS}_{\mathrm{t}}+\mathrm{a} 2 \mathrm{DMMGS}_{\mathrm{t}}+\mathrm{a} 3 \mathrm{HDCPO}_{\mathrm{t}}+\mathrm{a} 4 \mathrm{HRMGS}_{\mathrm{t}-1}+u_{\mathrm{t}}$ Tanda yang dihrapkan : a1, $<0 ; \quad a 2, a 3>0 ; \quad 0<a 4<1$

2. Fungsi struktural penawaran (supply) minyak goreng $\mathrm{SPMGS}_{\mathrm{t}}=\mathrm{b0}+\mathrm{b} 1 \mathrm{HRMGSt}+\mathrm{b} 2 \mathrm{HDCPOt}+\mathrm{b} 3 \mathrm{QMGt}+\mathrm{b} 4 \mathrm{STMGS}_{\mathrm{t}}+\mathrm{b} 5 \mathrm{DMOt}+\mathrm{b} 6 \mathrm{TKNLGt}+u_{\mathrm{t}}$ Tanda yang diharapkan : b2<0; b1, b3, b4, b5, b6 >0;

3. Fungsi struktural (permintaan) demand minyak goreng $\mathrm{DMMGS}_{\mathrm{t}}=\mathrm{c0}+\mathrm{c} 1 \mathrm{HRMGS}_{\mathrm{t}}+\mathrm{c} 2 \mathrm{PDPTN}_{\mathrm{t}}+\mathrm{c} 3 \mathrm{HRMGK}_{\mathrm{t}}+\mathrm{C} 4 \mathrm{DMMGS}_{\mathrm{t}-1}+u_{\mathrm{t}}$ Tanda yang diharapkan : c1<0; c2, c3>0 $0<\mathrm{c} 4<1$

4. Fungsi struktural luas areal kelapa sawit LAKS $_{\mathrm{t}}=\mathrm{d} 0+\mathrm{d} 1 \mathrm{SKBNGt}_{-1}+\mathrm{d} 2 \mathrm{HDCPO}_{\mathrm{t}}+\mathrm{d} 3 \mathrm{HRKRT}_{\mathrm{t}-1}+\mathrm{d} 4 \mathrm{LAKS}_{\mathrm{t}-1}+u_{\mathrm{t}}$ Tanda yang diharapkan : d1, d3 $<0 \quad ; \mathrm{d} 2,>0 ; 0<\mathrm{d} 4<1$

5. Fungsi struktural harga CPO Domestik $\mathrm{HDCPO}_{\mathrm{t}}=\mathrm{e} 0+\mathrm{e} 1 \mathrm{SPCPO}_{\mathrm{t}}+\mathrm{e} 2 \mathrm{DMCPO} \mathrm{t}_{\mathrm{t}}+\mathrm{e} 3 \mathrm{HRMGSt}+\mathrm{e} 4 \mathrm{VXCPOt}+u \mathrm{t}$ Tanda yang diharapkan ; e1<0 ; e2, e3, e4 $>0$

6. Fungsi struktural produktivitas kelapa sawit $\mathrm{YKS}_{\mathrm{t}}=$ fo $+\mathrm{f} 1 \mathrm{HDCPO}_{\mathrm{t}}+\mathrm{f} 2 \mathrm{UPTKR}_{\mathrm{t}}+\mathrm{f} 3 \mathrm{YKS}_{\mathrm{t}-1}+u_{\mathrm{t}}$ Tanda yang diharapkan : $\mathrm{f} 2<0 ; \mathrm{f} 1>0 ; 0<\mathrm{f} 3<1$

7. Fungsi struktural ekspor CPO Indonesia $\mathrm{VXCPO}_{\mathrm{t}}=\mathrm{go}+\mathrm{g} 1 \mathrm{QCPO}_{\mathrm{t}}+\mathrm{g} 2 \mathrm{HXCPOt}+\mathrm{g} 3 \mathrm{NTRP}_{\mathrm{t}}+\mathrm{g} 4 \mathrm{DMCPOt}+\mathrm{g} 5 \mathrm{VXCPOt} 1+u_{\mathrm{t}}$ Tanda yang diharapkan : g1, g2, g3 $>0 ; \mathrm{g} 4<0 ; 0<\mathrm{g} 5<1$

8. Fungsi identitas produksi CPO $\mathrm{QCPO}_{\mathrm{t}}=\mathrm{YKS}_{\mathrm{t}} \times \mathrm{LAKS}_{\mathrm{t}}$

9. Fungsi identitaspenawaran (supply $\mathrm{CPO}$ ) Indonesia $\mathrm{SCPO}=\mathrm{QCPOt}-\mathrm{VXCPOt}+\mathrm{IMCPO}+\mathrm{STCPOt}$

Keterangan : $\mathrm{a0}, \mathrm{b0}, \mathrm{c0}, \mathrm{d0}, \mathrm{e0}, \mathrm{f0}, \mathrm{g} 0$ $=$ Intersep $u_{\mathrm{t}}$ $=$ kesalahan pengganggu (error term) tahun ke $\mathrm{t}$ ai, bi ,ci, di, ei, fi $=$ Parameter yang diduga $(1,2,3 \ldots .$. $\mathrm{HRMGS}_{\mathrm{t}}$ = Harga rill minyak goreng pada tahun ke $t$ HRMGS $_{\mathrm{t}-1}$ $\mathrm{VXCPO}_{\mathrm{t}-1}$ = Lag 1 tahun harga rill minyak goreng sawit = lag 1tahun volume ekspor CPO Indonesia $\mathrm{DMMGS}_{\mathrm{t}-1}$ HRKRT $_{\text {t-1 }}$ = lag 1 tahun permintaan minyak goreng sawit = lag 1 tahun harga karet Indonesia SPMGS $_{t}$ = Penawaran minyak goreng sawit pada tahun ke $\mathrm{t}$ YKS $_{\mathrm{t}-1}$ = Lag 1 tahun produktivitas kelapa sawit DMOt DMMGS $_{\mathrm{t}}$ = Kebijakan Domestik Market Obligation pada tahun ke $\mathrm{t}$ = Permintaan minyak goreng sawit pada tahun ke $\mathrm{t}$ $\mathrm{HDCPO}_{\mathrm{t}}$ $=$ Harga rill CPO domestik pada tahun ke $\mathrm{t}$ 


\begin{tabular}{|c|c|}
\hline $\mathrm{HXCPO}_{\mathrm{t}}$ & $=$ Harga ekspor CPO pada tahun ke $t$ \\
\hline $\mathrm{DMCPO}_{\mathrm{t}}$ & $=$ Permintaan $\mathrm{CPO}$ pada tahun ke $\mathrm{t}$ \\
\hline $\mathrm{SPCPO}_{\mathrm{t}}$ & $=$ Penawaran $\mathrm{CPO}$ pada tahun ke $\mathrm{t}$ \\
\hline IMCPOt & $=$ impor $\mathrm{CPO}$ Indonesia pada tahun ke $\mathrm{t}$ \\
\hline STCPOt & = stok CPO Indonesia pada tahun ke t \\
\hline $\mathrm{SKBNG}_{\mathrm{t}-1}$ & = Lag satu tahun Tingkat suku bunga \\
\hline TKNLGA $_{t}$ & $=$ Teknologi pada industri minyak goreng pada tahun ke $\mathrm{t}$ \\
\hline $\mathrm{HRMGK}_{\mathrm{t}}$ & $=$ Harga rill minyak goreng kelapa pada tahun ke $\mathrm{t}$ \\
\hline $\mathrm{QCPO}_{\mathrm{t}}$ & $=$ Produksi $\mathrm{CPO}$ pada tahun ke $\mathrm{t}$ \\
\hline $\mathrm{YKS}_{\mathrm{t}}$ & $=$ Produktivitas kelapa sawit pada tahun ke $\mathrm{t}$ \\
\hline LAKS $_{t}$ & $=$ Luas areal kelapa sawit pada tahun ke $\mathrm{t}$ \\
\hline$U^{U P T K R_{t}}$ & $=$ Upah rill tenaga kerja pada tahun ke $\mathrm{t}$ \\
\hline STMGS $_{t}$ & = Stok minyak goreng pada tahun ke t \\
\hline PDPTN $_{t}$ & $=$ pendapatan perkapita pada tahun ke $\mathrm{t}$ \\
\hline $\mathrm{VXCPO}_{\mathrm{t}}$ & $=$ Voulume Ekspor CPO pada tahun ke t \\
\hline $\mathrm{NTRP}_{t}$ & $=$ Nilai tukar Rupiah terhadap Dollar Amerika pada tahun $\mathrm{k}$ \\
\hline
\end{tabular}

Sarkowo (2005), menyatakan suatu persamaan dapat dikatakan teridentifikasi (identified) apabila perkiraan parameter struktural dapat diperoleh dari perkiraan parameter bentuk reduksi. Persamaan yang identified dapat bersifat tepat teridentifikasi (exactlyidentified), terlalu teridentifikasi (overidentified), atau kurang teridentifikasi (underidentifiedl). Persamaan yang digunakan memiliki predetermined variable, sehingga berlaku aturan :

$$
\mathrm{K}-\mathrm{k} \geq \mathrm{m}-1
$$

Model yang dirumuskan di dalam penelitian ini terdiri dari tujuh persamaan struktural dan dua persamaan identitas. Model ini juga terdiri dari sembilan peubah endogen bedakala, dua belas variabel eksogen beda kala, dua buah peubah lag eksogen dan empat peubah lag endogen . Variabel predetermained terdiri dari peubah eksogen beda kala, peubah lag eksogen dan peubah lag endogen dan total keseluruhan variabel predetermained adalah 18 variabel. Berdasarkan aturan identifikasi model diatas, maka persamaan yang dibangun di dalam penelitian ini termasuk kategori overidentified.

Elastisitas adalah ukuran tingkat kepekaan suatu variabel respon pada suatu persamaan terhadap perubahan dari peubah penjelas. Penentuan nilai elastisitas adalah sebagai berikut:

1. Elastisitas jangka pendek (short run)

$E S R=a i$

Dimana : ESR = Elastisitas peubah respon (Yt) terhadap peubah penjelas (Xij) dalam jangka pendek).

$\mathrm{Ai}=$ Parameter dugaan peubah respon Xij

= Rata-rata peubah penjelas Xij

= Rata-rata peubah respon Yt

2. Elastisitas jangka panjang (long run)

$E L R=$

Dimana:

ELR= Elastisitas peubah respon $(Y t)$ terhadap peubah penjelas (Xij) dalam jangka panjang

an = Nilai parameter dugaan peubah bedakala.

Validasi model dilakukan untuk mengetahui apakah model cukup valid untuk membuat suatu simulasi kebijakan sehingga dapat menganalisis sejauh mana model tersebut dapat merefleksikan dengan baik atau mewakili dunia nyata. Simulasi kebijakan yang digunakan dalam penelitian ini berupa simulasi perubahan stok MGS sebesar $5 \%$, simulasi pendapatan perkapita sebesar $15 \%$ dan 
simulasi harga minyak goreng kelapa sebesar $10 \%$. Kriteria statistik yang sering digunakan untuk validasi penggunaan model ekonometrika :

Root Mean Square Error (RMSE) =

Root Mean Square Percent Error(RMSPE) =

Theil's Inequality Cofficient $(U)=$

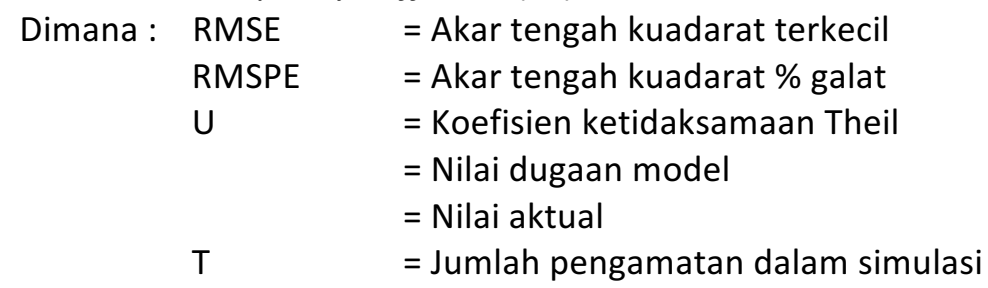

Statistik RMSPE berguna untuk mengukur seberapa jauh nilai-nilai peubah endogen hasil pendugaan menyimpang dari alur-alur nilai-nilai aktualnya dalam ukuran relatif (\%). Nilai statistik $U$ bermanfaat untuk mengetahui kemampuan model untuk analisis simulasi historis maupun peramalan. Semakin kecil nilai RMSE, RMSPE, dan U maka semakin baik pendugaan model. Nilai $U$ berkisar antara 0 dan 1 . Jika $U=0$, maka pendugaan model sempurna. Untuk melihat keeratan arah (slope) antara aktual dengan hasil yang disimulasi, dilihat dari nilai koefisien determinasinya $\left(R^{2}\right)$. Pada dasarnya semakin kecil nilai RMSPE dan U-Theil's dan makin besar nilai $\mathrm{R}^{2}$, maka pendugaan model semakin baik.

HASIL DAN PEMBAHASAN

Pendugaan Model Dan Keterkaitan Dinamika Harga MGS Terhadap Perkebunan Kelapa Sawit Indonesia Blok 1. Pasar Minyak Goreng Sawit

\section{Pendugaan Model Harga Minyak Goreng Sawit}

Nilai koefisien determinasi pada persamaan harga minyak goreng sawit Indonesia adalah sebesar 0.9852 artinya persamaan harga minyak goreng sawit Indonesia dapat dijelaskan oleh variabel-variabel independen yang terdapat dalam model tersebut sebesar $98,52 \%$ dan sisanya sebesar $1,48 \%$ dijelaskan oleh variabel lain yang terdapat diluar model. Tanda parameter semua variabel sesuai dengan teori ekonomi. Harga rill MGS lebih responsif terhadap perubahan penawaran MGS, peningkatan 1 ton penawaran MGS menyebabkan penurunan harga rill MGS sebesar 0,00001 $\mathrm{Rp} / \mathrm{Kg}$. Sementara pada penelitian Zulkifli (2000), setiap kenaikan 1000 ton penawaran MGS (keadaan ceteris paribus) akan menyebabkan penurunan harga MGS sebesar 396 Rp/Ton.

Tabel 2. Hasil Estimasi Faktor-Faktor yang Mempengaruhi harga minyak goreng sawit Indonesia

\begin{tabular}{ccccc}
\hline Variabel & Parameter Estimasi & Prob. & ESR & ELR \\
\hline Intercep $_{\mathrm{t}}$ & 16,40037 & 0,0893 & & \\
SPMGS $_{\mathrm{t}}$ & $-0,00001$ & 0,6063 & $-1,05$ & $-1,72$ \\
DMMGS $_{\mathrm{t}}$ & $7,145 \mathrm{E}-6$ & 0,7984 & 0,53 & 0,86 \\
HDCPO $_{\mathrm{t}}$ & 1,188597 & $*<, 0001$ & 0,86 & 1,40 \\
HRMGS $_{\mathrm{t} 1}$ & 0,387268 & $*<, 0001$ & & \\
\hline
\end{tabular}

Keterangan: * Nyata pada taraf $5 \%$

Harga rill CPO domestik berpengaruh nyata pada taraf 99,99\% terhadap harga rill MGS dan harga rill MGS responsif terhadap harga rill CPO domestik dalam jangka panjang dengan nilai elastisitas sebesar 1,4. Penelitian ini menunjukkan bahwa harga rill CPO berpengaruh sangat nyata terhadap harga MGS domestik sesuai dengan penelitian yang dilakukan oleh Zulkifli (2000) dimana harga CPO merupakan faktor yang dominan dalam mempengaruhi gejolak harga minyak goreng sawit domestik. Hasil penelitian ini pun telah sesuai dengan teori ekonomi, bahwa menurut Soekartawi 
(2002) harga suatu barang tidak hanya dipengaruhi oleh permintaan dan penawaran saja, tetapi dipengaruhi juga oleh harga barang lain dan harga input produksi.

\section{Pendugaan Model Penawaran Minyak Goreng Sawit}

Nilai koefisien determinasi pada persamaan penawaran minyak goreng sawit Indonesia adalah sebesar 0.9966 artinya persamaan penawaran minyak goreng sawit Indonesia dapat dijelaskan oleh variabel-variabel independen yang terdapat dalam model tersebut sebesar 99,66 \% dan sisanya sebesar 0,34 \% dijelaskan oleh variabel lain yang terdapat diluar model. Penawaran MGS responsif terhadap perubahan stok minyak goreng sawit, bisa dilihat dari nilai elastisitasnya yaitu 1. Peningkatan 1 ton stok MGS apabila dilempar kepasar akan menyebabkan peningkatan penawaran MGS sebesar 7,15 ton. Harga rill CPO berpengaruh negatif terhadap penawaran MGS pada taraf nyata 99,99\% dikarenakan meningkatnya biaya input akan mengurangi penggunaan input dan sesuai dengan penelitian Sitohang (2008) akan tetapi harga rill CPO domestik tidak berpengaruh nyata pada penelitian tersebut.

Tabel 3. Hasil Estimasi Faktor-Faktor yang Mempengaruhi Supply minyak goreng sawit Indonesia :

\begin{tabular}{ccrc}
\hline Variabel & Parameter Estimasi & Prob, & ESR \\
\hline Intercept & 80652,96 & 0,6571 & \\
HRMGSt & 2245,689 & 0,5286 & 0,02 \\
HDCPOT & $-3637,54$ & 0,4840 & $-0,02$ \\
QMGt & 0,054875 & $* * * 0,1009$ & 0,12 \\
STMGSt & 7,149820 & $*<, 0001$ & 1,00 \\
DMOt & 139259,8 & $* * * 0,1317$ & 0,01 \\
TKNLGAt & $-46799,0$ & $* * * 0,1188$ & $-0,14$ \\
\hline
\end{tabular}

R Square $=0.99664 ;$ Durbin-Watson $=2.393158 ; \mathrm{F}$ Value $=741.27$

Keterangan : * Nyata pada taraf $5 \%, \quad * * *$ Nyata pada taraf $15 \%$

Tanda variabel teknologi adalah satu-satunya variabel dengan tanda yang tidak sesuai dengan teori ekonomi bahwa menurut Soekartawi (2002) penawaran suatu barang dipengaruhi oleh teknologi dengan hubungan yang positif, akan tetapi harus memiliki keterampilan khusus karena penggunaan teknologi memiliki resiko dan ketidakpastian yang juga relatif tinggi.

\section{Pendugaan Model Permintaan Minyak Goreng Sawit}

Nilai koefisien determinasi pada persamaan permintaan minyak goreng sawit Indonesia adalah sebesar 0.8827 artinya persamaan permintaan minyak goreng sawit Indonesia dapat dijelaskan oleh variabel-variabel independen yang terdapat dalam model tersebut sebesar 88,27 \% dan sisanya sebesar 11,73 \% dijelaskan oleh variabel lain yang terdapat diluar model. Pada jangka panjang permintaan MGS responsif terhadap harga rill MGS. Peningkatan $1 \mathrm{Rp} / \mathrm{Kg}$ harga rill MGS dalam jangka panjang akan menyebabkan permintaan MGS sebesar 7775,63 ton MGS.

Tabel 4. Hasil Estimasi Faktor-Faktor yang Mempengaruhi Demand (permintaan) MGS Indonesia :

\begin{tabular}{cccrr}
\hline Variabel & Parameter Estimasi & Prob. & ESR & ELR \\
\hline Intercept & 53620,09 & 0,8889 & & 5,46 \\
HRMGSt & $-7775,63$ & 0,2183 & $-0,11$ & $-0,87$ \\
PDPTNt & 0,004242 & 0,8350 & 0,02 & $-3,88$ \\
HRMGKt & 4349,042 & 0,2522 & 0,07 & \\
DMMGS $_{\mathrm{t}-1}$ & 1,019299 & $*<, 0001$ & & \\
\hline \multicolumn{5}{c}{ R Square $=0,88267 ;$ Durbin-Watson $=2,875768 ; \mathrm{F}$ Value $=31,97$} \\
\hline
\end{tabular}

Keterangan : * Nyata pada taraf $5 \%$

Semua tanda dalam persamaan sesuai dengan teori ekonomi dan variabel yang membangun model sama dengan penelitian terdahulu oleh Wardani (2008), akan tetapi nilai koefisien 
determinasinya lebih besar yaitu 0,9736 dan dipengaruhi secara nyata oleh semua variabel independennya pada taraf nyata $5 \%$ hingga $10 \%$. Penelitian ini menggunakan variabel yang sama pula terhadap penelitian Zulkifli (2000), dimana semua parameter memberikan hasil yang sama dari tanda parameter maupun signifikansinya yaitu hanya dpengaruhi sangat nyata oleh lag 1 tahun permintaan MGS.

\section{Blok 2. Blok 2. Pasar Bahan Baku MGS ( CPO)}

\section{Pendugaan Model Harga CPO Domestik}

Nilai koefisien determinasi pada persamaan harga CPO domestik adalah 0.9498 artinya persamaan harga CPO domestik dijelaskan oleh variabel-variabel independen yang ada dalam model tersebut sebesar $94,98 \%$, sisanya $5,02 \%$ dijelaskan oleh variabel lain yang terdapat diluar model.

Tabel 6. Hasil Estimasi Faktor-Faktor yang Mempengaruhi Harga CPO domestik

\begin{tabular}{crrr}
\hline Variabel & Parameter Estimasi & Prob. & ESR \\
\hline Intercept & $-5,21481$ & 0,4066 & 0,29 \\
SPCPOt & $-2,35 \mathrm{E}-6$ & $* * * 0,1350$ & 0,79 \\
DMCPOt & $5,884 \mathrm{E}-6$ & $* * 0,0691$ & 0,60 \\
HRMGSt & 0,4394770 & $* 0,0011$ & 0,08 \\
VXCPOt & $3,253 \mathrm{E}-7$ & 0,6334 & \\
\hline \multicolumn{4}{r}{ R Square $=0.94984 ;$ Durbin-Watson $=1.73044 ;$} \\
\hline Keterangan :
\end{tabular}

Permintaan CPO domestik adalah variabel yang mempunyai nilai parameter yang lebih tinggi. Peningkatan 1 ton permintaan CPO akan meningkatkan harga rill CPO sebesar 0,000006 Rp/Kg. Harga rill MGS berpengaruh secara signifikan terhadap harga rill CPO domestik pada taraf $99 \%$. Harga rill MGS mampu menstimulasi harga CPO domestik. Menurut Irawan (2010), saat penawaran untuk barang atau jasa tertentu meningkat, permintaan turunan bagi faktor-faktor produksi yang dibutuhkan dalam memproduksi barang atau jasa ini pun akan meningkat, oleh karenanya keadaan ini pun memacu peningkatan harga bagi faktor-faktor produksi (dalam model ini adalah harga rill CPO domestik). Volume ekspor tidak berpengaruh nyata terhadap harga rill CPO domestik dikarenakan adanya pengawasan harga CPO dipasar oleh BAPPEBTI.

\section{Pendugaan Model Volume Ekspor CPO Indonesia}

Nilai koefisien determinasi pada persamaan volume ekspor CPO Indonesia adalah sebesar 0.9878 artinya persamaan volume ekspor CPO dapat dijelaskan oleh variabel-variabel independen yang terdapat dalam model tersebut sebesar $98,78 \%$ dan sisanya sebesar 1,22 \% dijelaskan oleh variabel lain yang terdapat diluar model.

Tabel 8. Hasil Estimasi Faktor-Faktor yang Mempengaruhi Volume Ekspor CPO Indonesia :

\begin{tabular}{lrrrr}
\hline \multicolumn{1}{c}{ Variabel } & Parameter Estimasi & Prob. & ESR & ESR \\
\hline Intercept & 1694507 & 0,0868 & & \\
QCPOt & 0,480900 & $* 0,0082$ & 0,71 & 1,95 \\
HXCPOt & 64506,14 & 0,6634 & 0,03 & 0,10 \\
NTRPt & 161,3123 & $* * * 0,1233$ & 0,15 & 0,42 \\
DMCPOt & $-1,37350$ & $* 0,0022$ & $-0,69$ & $-1,90$ \\
VXCPOT1 & 0,637240 & $* 0,0031$ & & \\
\hline
\end{tabular}

$\mathrm{R}$ Square $=0.98782 ;$ Durbin-Watson $=2.031406 ; \mathrm{F}$ value $=259.47$

Keterangan: * Nyata pada taraf $5 \%, \quad * * *$ Nyata pada taraf $15 \%$ 
Semua tanda parameter yang dihasilkan telah sesuai dengan teori ekonomi. Semua variabel berpengaruh nyata terhadap volume ekspor kecuali harga ekspor, hal ini dikarenakan adanya penetapan pajak ekspor maupun kebijakan pemerintah melalui DMO. Elastisitas produksi CPO terhadap volume ekspor CPO adalah sebesar 0,48 , artinya setiap kenaikan produksi CPO sebesar 1 ton akan mengakibatkan volume ekspor meningkat sebesar 0,48 ton volume ekspor CPO. Hal ini sesuai dengan penelitian Zulkifli (2000) yang menunjukkan bahwa produksi CPO merupakan satu satunya variabel yang berpengaruh secara signifikan dimana respon volume ekspor terhadap produksi CPO pada penelitian tersebut bersifat inelastis sementara pada penelitian respon volume ekspor terhadap produksi CPO bersifat elastis. Elastisitas harga ekspor CPO terhadap volume ekspor CPO adalah sebesar 64506,14 , artinya setiap kenaikan nilai tukar Rupiah sebesar 1Rp/U\$ Dollar akan mengakibatkan volume ekspor meningkat sebesar 1,37 ton volume ekspor CPO. Volume ekspor CPO responsif terhadap permintaan CPO domestik dan penawaran CPO domestik dengan nilai elastisitas 1,9 dan 1,95 . Nilai elastisitas pada produksi CPO pada penelitian terdahulu oleh Wardani (2008) menunjukkan bahwa pada jangka pendek volume CPO responsif terhadap produksi CPO pada jangka pendek dengan nilai elastisitas 1,8 .

\section{Blok 3. Perkebunan Kelapa Sawit Indonesia}

\section{Pendugaan Model Luas Areal Kelapa Sawit Indonesia}

Nilai koefisien determinasi pada persamaan luas areal kelapa sawit Indonesia adalah sebesar 0.9264 artinya persamaan luas areal kelapa sawit Indonesia dapat dijelaskan oleh variabel-variabel independen yang terdapat dalam model tersebut sebesar $92,64 \%$ dan sisanya sebesar 7,36 \% dijelaskan oleh variabel lain yang terdapat diluar model.

Tabel 5. Hasil Estimasi Faktor-Faktor yang Mempengaruhi Luas Areal Kelapa Sawit di Indonesia :

\begin{tabular}{crrr}
\hline Variabel & Parameter Estimasi & Prob. & ESR \\
\hline Intercept & 5134875 & $<, 0001$ & $-0,01$ \\
SKBNGt1 & $-8646,07$ & 0,6900 & 0,31 \\
HDCPOt & 54317,96 & $* 0,0007$ & 0,21 \\
HRKRTt1 & 45,27977 & $* 0,0007$ & $-0,58$ \\
UPTKRt & $-123,310$ & $* 0,0031$ & $-0,01$ \\
\hline
\end{tabular}

R-Square $=0,92648 ;$ Durbin-Watson $=0,948497 ; \mathrm{F}$ Value $=53,56$

Keterangan : * Nyata pada taraf $5 \%$

Tanda parameter yang dihasilkan oleh lag 1 tahun harga karet tidak sesuai dengan teori ekonomi, hal ini dikarenakan tanaman ini merupakan tanaman tahunan dimana petani tidak mudah dalam mengambil keputusan dijangka pendek dan pada saat harga karet meningkat, luas areal kelapa sawit juga meningkat dikarenakan masih tersedianya lahan kosong yang tidak produktif yang akan ditanami karet saat harga karet meningkat. Peningkatan luas areal kelapa sawit akibat peningkatan harga CPO didukung oleh pendapat Risza (2012) yang menyatakan bahwa keberhasilan suatu usaha perkebunan ditentukan oleh pengaruh kondisi ekonomi yang sedang berlangsung pada waktu usaha itu dilakukan, antara lain fluktuasi harga jual komoditas yang berlaku dipasar dan kenaikan harga sarana produksi (input produksi), dan sebagainya. Kenaikan harga rill CPO mampu menstimulasi perkembangan luas areal kelapa sawit Indonesia, dimana kenaikan 1Rp/Kg harga rill CPO atau 113 $\mathrm{Rp} / \mathrm{Kg}$ (harga nominal) akan meningkatkan luas areal kelapa sawit sebesar 54317,96 Ha. Suku bunga juga berpengaruh negatif terhadap luas areal, dan ini sesuai dengan teori ekonomi sebagaimana yang dikatakan oleh Sukirno (1981) bahwa tingkat suku bunga merupakan faktor yang sangat penting bagi para pengusaha dalam berinvestasi, karena apabila tingkat suku bunga meningkat, maka investasi pengusaha akan berkurang dan akan memilih menabung. Peningkatan lag 1 tahun tingkat suku bunga serta upah tenaga kerja memberikan tanda yang sesuai dengan penelitian yang dilakukan oleh Zulkifli 
(2000) dan sesuai dengan teori ekonomi. Variabel upah tenaga kerja sama-sama memberikan hasil yang signifikan, akan tetapi berbeda dengan tingkat pengaruh variabel lag 1 tahun suku bunga rill yang memberikan tanda yang signifikan pada penelitian Zulkifli (2000), sementara pada penelitian ini memberikan pengaruh yang tidak signifikan

\section{Pendugaan Model Produktivitas Kelapa Sawit Indonesia}

Nilai koefisien determinasi pada persamaan produktivitas kelapa sawit Indonesia adalah sebesar $0.7458 \%$ artinya persamaan produktivitas kelapa sawit Indonesia dapat dijelaskan oleh variabel-variabel independen yang terdapat dalam model tersebut sebesar $74,58 \%$ dan sisanya sebesar $25,42 \%$ dijelaskan oleh variabel lain yang terdapat diluar model. Tanda parameter yang dihasilkan sesuai dengan teori ekonomi. Produktivitas kelapa sawit tidak responsif terhadap upah rill tenaga kerja dan harga rill CPO domestik, dapat dilihat dari nilai elastisitas jangka panjang maupun jangka pendeknya yang sangat rendah.

Tabel 7. Hasil Estimasi Model Produktivitas kelapa sawit

\begin{tabular}{crrrrr}
\hline Variabel & Parameter Estimasi & Prob. & ESR & \multicolumn{2}{c}{ ELR } \\
\hline Intercept & 0,471795 & 0,1520 & & & \\
HDCPOt & 0,002422 & 0,3039 & & $\mathbf{0 , 0 3}$ & 0,16 \\
UPTKRt & $-4,65 \mathrm{E}-6$ & 0,5507 & & $-0,05$ & $-0,26$ \\
YKSt1 & 0,809916 & $* 0,0003$ & & & \\
\hline R-Square $=0.74585$ & $;$ & Durbin-Watson $=2.115699$ & $;$ & F value $=17.61$ \\
\hline
\end{tabular}

Keterangan : * Nyata pada taraf $5 \%$

Produktivitas kelapa sawit dipengaruhi secara nyata oleh variabel lag produktivitas kelapa sawit, dan ini sesuai dengan penelitian Askadarimi (2007) bahwa peningkatan produktivitas tahun sebelumnya akan meningkatkan produktivitas tahun analisis. Variabel harga rill CPO domestik pada penelitian Askadarimi (2007) juga tidak berpengaruh signifikan terhadap produktivitas kelapa sawit dan sesuai dengan penelitian ini. Sementara nilai elastisitasnya pada jangka panjang maupun jangka pendek tidak responsif terhadap perubahan variabel independennya.

\section{Dampak Dinamika Harga Mgs Terhadap Perkebunan Kelapa Sawit Indonesia}

\section{Simulasi Penurunan Stok Minyak Goreng Sawit $5 \%$}

Tabel 9 menunjukkan hasil simulasi berdasarkan penurunan stok minyak goreng sawit domestik sebesar $5 \%$.

Tabel 9. Hasil Simulasi penurunan Stok Minyak Goreng Sawit Sebesar $5 \%$

\begin{tabular}{crrr}
\hline \multirow{2}{*}{ Variabel } & Nilai Dasar & \multicolumn{2}{c}{ Skenario Simulasi STMGSt Turun 5 \% } \\
\cline { 2 - 4 } & Predicted Mean & Predicted Mean & $\% \Delta$ \\
\hline HRMGSt & 45,0301 & 48,3912 & 7,46 \\
DMMGSt & 2799225 & 2773090 & $-0,93$ \\
SPMGSt & 4071392 & 3870504 & $-4,93$ \\
HDCPOt & 30,3009 & 31,5957 & 4,27 \\
VXCPOt & 7615652 & 7698098 & 1,08 \\
QCPOt & 11278625 & 11450064 & 1,52 \\
SPCPOt & 3715047 & 3804041 & 2,40 \\
LAKSt & 4949807 & 5020138 & 1,42 \\
YKSt & 2,1869 & 2,1901 & 0,15 \\
\hline
\end{tabular}

Penurunan stok MGS yang ditahan sebesar $5 \%$ berdampak kepada seluruh variabel dimana ada variabel yang mengalami peningkatan dan ada yang mengalami penurunan. Penurunan stok MGS diduga akan meningkatkan harga MGS sebesar 7,46\% dan akan menjadi insentif bagi produsen MGS dikarenakan apabila stok yang dilempar kepasar dikurangi maka akan meningkatkan harga MGS, 
karena dengan dikuranginya stok yang dilempar kepasar maka akan menyebabkan penawaran dipasar menurun, hal ini akan meningkatkan harga MGS dan akan menjadi insentif bagi produsen dipasar MGS maupun di pasar bahan baku CPO. Penurunan stok 5\% akan menjadi insentif bagi produsen kelapa sawit sehingga luas areal dan produktivitas akan meningkat dikarenakan meningkatnya harga outputnya akan meningkatkan harga bahan baku pembuatan MGS. Penurunan stok MGS sebesar $5 \%$ akan menjadi insentif bagi perkebunan kelapa sawit Indonesia melalui respon positif luas areal dan produktivitas kelapa sawit yang masing-masing mengalami peningkatan sebesar $1,42 \%$ dan $0,15 \%$, akan tetapi akan meningkatkan harga MGS. Hal ini tidak sesuai dengan program pemerintah dalam stabilisasi harga MGS melalui pelaksanaan stok penyangga yang berupaya meningkatkan stok supaya harga tidak melonjak (Sekretaris Kabinet Republik Indonesia, 2013).

\section{Simulasi Peningkatan Pendapatan Perkapita Sebesar $15 \%$}

Pada penelitian ini Pendapatan perkapita disimulasikan meningkat sebesar 5\%. Peningkatan pendapatan perkapita sebesar $15 \%$ akan meningkatan permintaan MGS sebesar 0,23\%. Hasil penelitian ini sesuai dengan teori ekonomi oleh Soekartawi (2002) menyatakan bahwa perubahan tingkat pendapatan seseorang akan mempengaruhi banyaknya jumlah barang yang dikonsumsi. Peningkatan permintaan MGS akan menimbulkan harga meningkat sebesar 0,18 sehingga menjadi insentif untuk produsen untuk memproduksi lebih banyak sehingga penawaran MGS meningkat $0,002 \%$.

Tabel 10. Hasil simulasi kenaikan pendapatan perkapita sebesar $15 \%$

\begin{tabular}{crrr}
\hline \multirow{2}{*}{ Variabel } & Nilai Dasar & \multicolumn{2}{c}{ Skenario Simulasi PDPTNt naik $15 \%$} \\
\cline { 2 - 4 } & Predicted Mean & Predicted Mean & $\%$ \\
\hline HRMGSt & 45,0301 & 45,1135 & 0,185 \\
DMMGSt & 2799225 & 2805716 & 0,232 \\
SPMGSt & 4071392 & 4071464 & 0,002 \\
HDCPOt & 30,3009 & 30,3326 & 0,105 \\
VXCPOt & 7615652 & 7617863 & 0,029 \\
QCPOt & 11278625 & 11283221 & 0,041 \\
SPCPOt & 3715047 & 3717433 & 0,064 \\
LAKSt & 4949807 & 4951533 & 0,035 \\
YKSt & 2,1869 & 2,1870 & 0,005 \\
\hline
\end{tabular}

Peningkatan penawaran sebagai respon dari peningkatan harga sesuai dengan penelitian sebelumnya oleh Rahayu (2008) pada komoditi beras bahwa dampak kebijakan harga berpengaruh positif terhadap kesejahteraan petani melalui sisi penawaran. Dalam meningkatkan produksi MGS diperlukan bahan baku (CPO) yang lebih besar sehingga permintaan CPO meningkat yang akan berakibat terhadap peningkatan harga CPO domestik sebesar0,1\%. Peningkatan harga CPO akan mendorong produsen berproduksi lebih banyak sehingga volume ekspor juga akan meningkat sebesar $0,03 \%$. Industri CPO akan membutuhkan TBS yang lebih besar sehingga respon petani meningkatkan produksi adalah dengan meningkatkan produktivitas sebesar $0,005 \%$ dan luas areal kelapa sawit $0,035 \%$. Simulasi peningkatan pendapatan per kapita ini sesuai dengan simulasi peningkatan pendapatan yang dilakukan oleh Zulkifli (2000) mengenai dampak kebijakan domestik terhadap keragaan industri kelapa sawit Indonesia menunjukkan bahwa permintaan CPO oleh neara importir akan merespon positif kenaikan pendapatan tersebut, dimana tingginya permintaan tersebut akan menyebabkan peningkatan harga CPO dunia. kenaikan harga CPO tersebut akan menjadi insentif bagi produsen CPO untuk meningkatkan volume ekspor.

\section{Simulasi Peningkatan Harga Rill Minyak Goreng Kelapa Sebesar $10 \%$}

Minyak goreng kelapa merupakan barang substitusi dari MGS, apabila terjadi perubahan harga MGS atau harga minyak goreng kelapa akan berdampak terhadap harga substitusinya, akibat 
pergeseran permintaan konsumen. Hasil simulasi peningkatan harga minyak goreng kelapa sebesar $10 \%$ mampu menggeser konsumsi masyarakat terhadap konsumsi MGS, hal ini terlihat dari meningkatnya permintaan MGS sebesar 1,04\% yang menyebabkan harga MGS meningkat sebesar $0,83 \%$, hasil penelitian ini sesuai dengan teori Sukirno (2002) yang mengatakan bahwa sekiranya harga barang pengganti bertambah murah maka barang yang digantikannya akan mengalami penurunan dalam permintaan. Peningkatan harga MGS akan menstimulasi produsen untuk memproduksi lebih besar, terlihat dari meningkatnya penawaran MGS sebesar $0,01 \%$. Meningkatnya permintaan CPO untuk bahan baku industri MGS akan meningkatkan harga CPO sebesar 0,47\% sehingga produksi CPO akan meningkat sebesar $0,18 \%$ sebagai respon dari meningkatnya harga output. Peningkatan harga minyak goreng kelapa sebesar $10 \%$ akan meningkatkan harga MGS sebesar $0,83 \%$ yang akan menyebabkan harga ril CPO domestik juga meningkat sebesar 0,47 . Hasil penelitian ini sesuai dengan teori Lipsey et al (1994) yang menyatakan bahwa besar kecilnya jumlah yang diminta akan suatu faktor produksi merupakan penentu harga faktor produksi tersebut bahkan penentu harga produk akhir suatu barang atau jasa.

Tabel 11. Hasil Simulasi Peningkatan harga minyak goreng kelapa sebesar $10 \%$

\begin{tabular}{crrr}
\hline \multirow{2}{*}{ Variabel } & Nilai Dasar & \multicolumn{2}{c}{ Skenario Simulasi HRMGKt naik $10 \%$} \\
\cline { 2 - 4 } & Predicted Mean & Predicted Mean & $\% \Delta$ \\
\hline HRMGSt & 45,0301 & 45,4054 & 0,83 \\
DMMGSt & 2799225 & 2828346 & 1,04 \\
SPMGSt & 4071392 & 4071713 & 0,01 \\
HDCPOt & 30,3009 & 30,44442 & 0,47 \\
VXCPOt & 7615652 & 7625398 & 0,13 \\
QCPOt & 11278625 & 11298890 & 0,18 \\
SPCPOt & 3715047 & 3725567 & 0,28 \\
LAKSt & 4949807 & 4957594 & 0,16 \\
YKSt & 2,1869 & 2,1873 & 0,02 \\
\hline
\end{tabular}

Tingginya produksi akan meningkatkan penawaran CPO sebesar 0,28 \% dan mendorong peningkatan volume eksor sebesar $0,13 \%$. Respon luas areal dan produktivitas kelapa sawit akibat tingginya permintaan CPO dan kelapa sawit adalah positif, dapat dilihat dari hasil simulasi bahwa peningkatan harga rill minyak goreng kelapa sebesar $10 \%$ akan bedampak terhadap luas areal dan produktivitas dengan peningkatan masing-masing sebesar $0,16 \%$ dan $0,02 \%$.

\section{KESIMPULAN}

Dinamika harga minyak goreng sawit Indonesia dipengaruhi oleh permintaan, penawaran minyak goreng sawit dan harga bahan baku (CPO). Sehubungan dengan itu, kebijakan pada sisi supply dan demand akan berdampak terhadap perkebunan kelapa sawit Indonesia. Penurunan stok minyak goreng sawit sebesar $5 \%$ pada sisi penawaran akan meningkatkan harga MGS, hal ini akan menjadi insentif bagi produsen minyak goreng maupun produsen bahan bakunya sehingga mendorong peningkatan luas areal dan produktivitas masing-masing sebesar $1,42 \%$ dan $0,15 \%$. Kebijakan dari sisi demand yaitu simulasi peningkatan pendapatan per kapita masyarakat sebesar $15 \%$ akan meningkatkan harga MGS dan menjadi insentif bagi produsen bahan baku dan akan direspon positif oleh perkebunan kelapa sawit Indonesia melalui peningkatan luas areal dan produktivitas masingmasing $0,035 \%$ dan $0,005 \%$. Begitupula dengan simulasi peningkatan harga minyak goreng kelapa sebesar $10 \%$ akan berdampak terhadap peningkatan luas areal dan produktivitas kelapa sawit masing-masing sebesar $0,16 \%$ dan $0,02 \%$. Sementara simulasi penurunan stok minyak goreng sawit sebesar 5\% mampu meningkatkan luas areal dan produktivitas kelapa sawit akan tetapi 
menyebabkan kondisi pasar minyak goreng sawit tidak stabil dikarenakan peningkatan harga minyak goreng sawit.

\section{DAFTAR PUSTAKA}

Amang, Beddu. Simatupang, Pantjar. Rachman, Anas. 1996. Ekonomi Minyak Goreng di Indonesia. IPB Press. Bogor.

Askadarimi, Imi. 2007. Analisis Faktor-Faktor Yang Mempengaruhi Perdagangan Minyak Sawit (CPO) Indonesia. IPB. Bogor.Skripsi

Irawan, Mul. 2010. The derived demand princiole / prinsip permintaan turunan. http://mulirawan.wordpress.com/2010/08/24/the-derived-demand principle-prinsip permintaan-turunan-2/ (diakses pada tanggal 9 maret 2014)

Lipsey, Richard G. Purvis, Douglas D. Steiner, Peter O. Courant, Paul N. 1995. Pengantar Mikro Ekonomi.Bina Rupa Aksara. Jakarta Barat.

Rahayu, Siti Endang. 2008. Analisis Dampak Kebijakan Harga Terhadap Kesejahteraan Petani Padi Di Indonesia. Digital Library Universitas Sebelas Maret. (Diakses pada tanggal 3 April 2014).

Risza, Suyatno. 2011. Upaya Peningkatan Produktivitas Kelapa Sawit. Penerbit Kanisius. Yogyakarta. Sarkowo, M. 2005. Dasar - Dasar Ekonometrika. Penerbit Andi. Yogyakarta

Sekretaris Kabinet Republik Indonesia. 2013.Stok Penyangga Pangan. http://www.setkab.go.id/artikel-10594-stok-penyangga-pangan.html (diakses pada tanggal 2 Juni 2014).

Sitohang, Bona.R.H. 2008. Pengaruh Ekspor CPO Terhadap Harga Minyak Goreng Sawit Indonesia. Skripsi. IPB. Bogor.

Soekartawi. 2002. Prinsip Dasar Ekonomi Pertanian. Teori dan Aplikasi. Jakarta. Raja Grafindo Persada.

Sukirno, Sadono. 1981. Pengantar Teori MakroEkonomi. LPFE - UI.

Sukirno, Sadono.2002. Pengantar Teori MikroEkonomi Edisi Ketiga .PT Raja Grafindo Persada. Jakarta Wardani, Wida. Dampak Kebijakan Perdagangan di Sektor Industri CPO Terhadap Keseimbangan Pasar Minyak Goreng Sawit Dalam Negeri. IPB. Bogor.Skripsi

Zulkifli. 2000. Dampak Liberalisasi Perdagangan Terhadap Keragaan Industri Kelapa Sawit Indonesia dan Perdagangan Minyak Inti Sawit Dunia.IPB. Bogor. Disertasi 